\title{
DISPOSITIVO ORTODÔNTICO UTILIZADO PARA TRACIONAMENTO DE DENTE INCLUSO EM POSIÇÃO DESFAVORÁVEL
}

Juliana REIS, Sara Barancelli TODERO, Aline Monise SEBASTIANI, Rafaela SCARIOT, Nelson REBELLATO

A impactação dental é comum em pacientes ortodônticos, caso o dente permaneça incluso, ou semi incluso, pode acarretar em diversas consequências: mau posicionamento vestibular ou lingual do dente impactado, migração de dentes vizinhos, perda da extensão do arco, reabsorção dentária interna, reabsorção radicular externa do próprio dente ou de dentes adjacentes, formação cística e infecção. Os tratamentos ortodôntico-cirúrgicos são empregados como uma tentativa para reposicionar o dente no arco dentário evitando a extração, principalmente se o dente em questão possui grande importância estética e/ou funcional para o devido equilíbrio e harmonia do arco dentário. Paciente F.N.A, gênero feminino, 12 anos de idade com presença do dente 37 incluso em posição horizontal foi submetida a ulectomia e instalação de um dispositivo ortodôntico para tentativa de tracionamento e verticalização desse dente. Foi realizada a colagem de um tubo na face vestibular do elemento 37 e utilizado um fio ortodôntico com memória elástica para o tracionamento. Após a fase inicial da mecânica, o dente verticalizou mas não irrompeu. Uma nova cirurgia foi realizada para trocar o posicionamento do tubo, a fim de direcionar a força para extrusão do dente. O dente irrompeu e encontra-se em perfeito alinhamento e função oclusal.

Palavras-Chave: Ortodontia; Erupção; Extrusão; Dente incluso. 